\title{
Coreopsis tinctoria Nutt. as a source of many colours
}

\author{
KATARZYNA SCHMIDT-PRZEWOŹNA*, ANNA MORALES VILLAVICENCIO, ANNA KICIŃSKA- \\ JAKUBOWSKA, KAROLINA ZAJĄCZEK, ANNA BRANDYS
}

\author{
Department of Innovative Textile Technologies \\ Institute of Natural Fibres \&Medicinal Plants \\ Wojska Polskiego 71B \\ 60-630 Poznań, Poland
}

coresponding author: kasia@iwnirz.pl

\section{Summary}

Introduction: Coreopsis_tinctoria Nutt. is an annual plant with small flowers in yellow and claret. In dyeing process, a whole range of colours can be obtained using various methods.

Objective: The aim of the study was to present a wide range of colors of the little-known plant $C$. tinctoria. and its health promoting properties.

Methods: In our research, we selected 3 types of wool: Polish Merino, Żelaźnieńska, and Polish Lowland Sheep and compared the colours obtained on these wools using 6 dyeing methods.

Results: The results indicate that the basic colour of wool influences the intensity of colour after dyeing as well as the type of the used mordant, which determines the obtained colour. A whole range of very intense colours was obtained from very small flowers of $C$. tinctoria.

Conclusions: Flowers are a very good and efficient raw material that gives intense colors on wool. An additional advantage is the plant's health-promoting properties. The plant is still little explored in this respect.

Key words: Coreopsis tinctoria Nutt., sheep wool, natural dyeing, mordants, medicinal properties

\section{Słowa klucze: Coreopsis tinctoria Nutt., wetna owcza, naturalne barwienie, właściwości lecznicze}

\section{INTRODUCTION}

Coreopsis is known as a dyeing plant, but has been also used in medicine. Coreopsis tinctoria Nutt. (Golden tickseed) belongs to Asteraceae family [15]. It is a plant native to North America. Its name is taken from the Greek "koris"(bug) related to the shape of seed [6]. Another name of the plant is tickseed. It occurs wild in the natural state in North America (from Saskatchewan and Minnesota to Louisiana, Texas and Arizona). It is also spread in Asia and New Zealand. In many countries it is grown as an ornamental plant on flowerbeds, in gardens as well as in green roof gardens [7]. The plant was introduced in Europe in 1835. It is cultivated in 
Spain, Poland, Portugal, Serbia, Great Britain, Austria, Belgium and other countries.

The plant grows about $50 \mathrm{~cm}$ tall. The flowers are interestingly coloured: the petals are bright yellow with claret and brown centres. It blooms from June to September. For dyeing purposes, the flowers are harvested in this period, whereas the seeds from June to October. In Great Britain, coreopsis is sown on meadows and roof gardens. It perfectly grows in these not very favourable conditions and also blooms for several months.

\section{Compounds of Coreopsis tinctoria Nutt.}

The following compounds were separated in inflorescences C. tinctoria: different flavonoids (marein, flavanomarein, quercetagetin-7-O-glucoside, okanin aurone, leptosidin, luteolin, apigenin), organic acids (3,4-dihydroxybenzoic acid, 4-hydroxybenzoic acid, chlorogenic acid and caffeic acid), organic ester: 4 - $O-\beta$-D-glucopyranosyl- $p$-coumaric acid methyl ester. The plant contains also: two flavonones: 2S-3', 5', 7-trihydroxyflavanone and (2R, 3R)-3,4',5,7-tetrahydroxyoflavanone and two sterols: stigmasterol-3-O- $\beta$-D-glucopyranoside and $\beta$-sitosterol. A group of scientists in China have discovered the new compound called okanin [8-10].

\section{Medicinal properties}

In folk medicine, the plant has been used to treat many conditions, such as bleeding, to control diabetes, and also as a vomiting agent as well as to treat diarrhoea (extract from the whole plant) and cardiovascular diseases. C. tinctoria flower is used as a drink and as a nutriment to reduce weight, high lipids and high blood sugar and improve the condition of the liver [11].

In traditional Indian, Chinese and Portuguese medicine, Coreopsis has been used for hundreds of years to treat many diseases. Tea flower infusions were used as a drink to treat hypertension [8] and hyperglycaemia. In the Department of Pharmacy, Guangdong, Provincial People's Hospital Guangzhou in China the research there was conducted on the assessment of antioxidant activity of the plant's flowers [12-14]. Other studies have shown that flavonoid-rich plant flowers increase glucose tolerance by restoring pancreas functions in streptozotocin-induced diabetic rats [15]. According to another China researches, flavonoids from $C$. tinctoria extracts showed anti- hyperlipidaemia effect, particularly in lowering triglycerides, reducing lipid deposition and protecting the liver function $[9,15]$.

Pharmacological studies have shown that Coreopsis has certain biological effects, including antioxidant $[7,12]$, antidiabetic $[7,14]$, antihypertensive [7], and cytoprotective [14].

As a result of these studies, therapeutic properties were discovered in the plant flowers, which requires further research. Nevertheless, it has been stated that the plant is a valuable raw material for food industry.

Sheep wool is a natural and biodegradable product obtained during shearing from sheep of many breeds. White and uniform wool plain wool are of the largest demand, because it is a raw material for crafters as well as for textile industry [17]. Currently, sheep wool and its fabrics are perceived as an ecological product used for the production of clothes and upholstery fabrics as well as used by artists to create works of art that can be seen in galleries, museums and public places. Sheep wool usually has a white or slightly creamy colour, so it is easy to be dyed any colour.

\section{MATERIALS AND METHODS}

\section{The plant material}

Flowers and tips of plants were harvested at the Experimental Stations of the Institute of Natural Fibres and Medicinal Plants in Pętkowo and in the Garden of Medicinal Plants of the Institute in Plewiska, Poland. The seeds of the plant were sown in spring. Harvesting was carried out during the flowering period from June to September. Flowers were dried at $30^{\circ} \mathrm{C}$. The dried flowers of the plant were used to create dyestuffs.

\section{Wool}

In these studies, the samples of washed wool coming from Polish sheep breeds with the thinnest and plain wool were used. These include: Polish Merino, Żelaźnieńska and Polish Lowland Sheep, taking into account the basic colour of wool [17, 18]. Laserscan was used to measure the thickness of the wool.

Table 1 presents the most important quality parameters of wool valuable for textile industry. Out of three breeds of sheep whose wool was used in the 
Table 1.

Quality parameters of wool of selected sheep breeds

\begin{tabular}{|l|l|l|l|l|l|l|l|l|l|}
\hline \multirow{2}{*}{ Wool sample } & Diameter & SD & CV & SF & Curvature & CF & Prickle factor & Length & SD \\
\cline { 2 - 9 } & {$[\mu \mathrm{m}]$} & {$[\mu \mathrm{m}]$} & {$[\%]$} & {$[\mu \mathrm{m}]$} & {$[\mathrm{deg} / \mathrm{mm}]$} & {$[\%]$} & {$[\%]$} & {$[\mathrm{mm}]$} & {$[\mathrm{mm}]$} \\
\hline Polish Merino & $\begin{array}{l}24.9 \\
(24.3 \div 26.2)\end{array}$ & 5.31 & 21.2 & 24.4 & $\begin{array}{l}108.34 \\
(105.2 \div 109.4)\end{array}$ & 86.9 & 13.1 & 68.0 & 9.5 \\
\hline Żelaźnieńska & $\begin{array}{l}29.3 \\
(29.1 \div 29.7)\end{array}$ & 6.78 & 23.2 & 29.1 & $\begin{array}{l}85.96 \\
(84.1 \div 87.7)\end{array}$ & 58.82 & 41.2 & 86.5 & 6.3 \\
\hline Polish Lowland Sheep & $\begin{array}{l}31.9 \\
(31.8 \div 32.2)\end{array}$ & 7.36 & 23.0 & 31.7 & $\begin{array}{l}94.94 \\
(91.0 \div 98.6)\end{array}$ & 42.84 & 57.2 & 85.0 & 9.0 \\
\hline
\end{tabular}

SD - standard deviation

$\mathrm{CV}$ - coefficient of variation

SF - spinning fineness

CF - comfort factor

research, the best material was derived from Polish Merino. It was characterized with the smallest thickness of $24.9 \mu \mathrm{m}$, standard deviation (SD) $5.31 \mu \mathrm{m}$, and a coefficient of variation $(\mathrm{CV})$ of $21.2 \%$, respectively. Spinning fineness (SF) provides information on the processing value of wool and the benefits for buyers and processors. In the case of Polish Merino, this parameter reached $24.4 \mu \mathrm{m}$. The curvature of this wool was high, $108.34 \mathrm{deg} / \mathrm{mm}$. The comfort factor $(\mathrm{CF})$ was $86.9 \%$ indicating a large proportion of fibers with a thickness higher than $30 \mu \mathrm{m}$, which is reflected in Prickle Factor 13.1\%. Polish Merino was also longer than other types of wool, on average $9.5 \mathrm{~mm}$.

The basic colour of wool was measured with a Konica Minolta cr-400 colourimeter using a standardized international method (Commission Internationale de
l'Eclairage) CIELab, according to which $\mathrm{L}^{*}$ describes the brightness of colour in the range from white (100) to black, a* describes the saturation of colours from red to green, $b^{*}$ describes the saturation of colours from yellow to blue. Tables 2, 3, and 4 present measurements of colours obtained on dyed wool according to two color description systems: spectrophotometric analysis and assessment of colour, according to Pantone Color System.

Tables 2, 3, 4 present colours in CIE Lab System. The CIE Lab colour space (also known as CIE $\mathrm{L}^{\star} \mathrm{a}^{\star} \mathrm{b}^{\star}$ is a colour space defined by the International Commission on Illumination (CIE) in 1976.

The Pantone Colour Matching System is a standardized colour reproduction system. By standardizing the colours, different manufacturers in different locations can refer to the Pantone system to assure the

Table 2.

Analysis of the colours obtained on Polish Merino wool

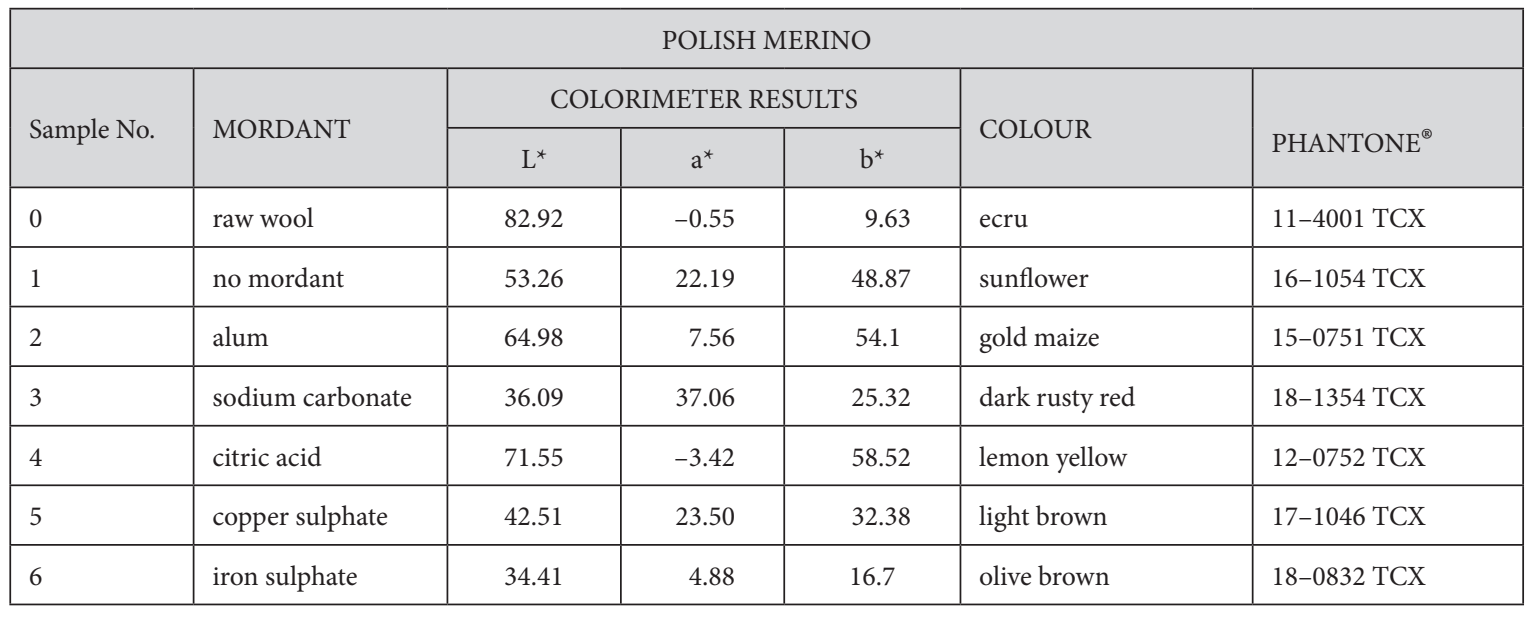

$\mathrm{L}^{*}-$ lightness

$\mathrm{a}^{*}$ - redness

$\mathrm{b}^{*}-$ yellowness 
Table 3.

Analysis of the colours obtained on Żelaźnieńska wool in dyeing process

\begin{tabular}{|c|c|c|c|c|c|c|}
\hline \multirow{2}{*}{ Sample No. } & \multirow{2}{*}{ MORDANT } & \multicolumn{7}{|c|}{ COLORIMETER RESULTS } & \multirow{2}{*}{ COLOUR } & \multirow{2}{*}{ PANTONE } \\
\cline { 3 - 5 } & & $\mathrm{L}^{*}$ & $\mathrm{a}^{*}$ & $\mathrm{~b}^{*}$ & & \\
\hline 0 & raw wool & 83.87 & 0.18 & 9.8 & white & $11-0106 \mathrm{TCX}$ \\
\hline 1 & no mordant & 56.36 & 19.28 & 50.63 & brown yellow & $15-0953 \mathrm{TCX}$ \\
\hline 2 & alum & 72.03 & 1.19 & 53.83 & mustard & $13-0752 \mathrm{TCX}$ \\
\hline 3 & sodium carbonate & 42.31 & 38.64 & 32.2 & light rusty red & $17-1452 \mathrm{TCX}$ \\
\hline 4 & citric acid & 76.74 & -7.77 & 55.4 & lemon yellow & $12-0752 \mathrm{TCX}$ \\
\hline 5 & copper sulphate & 41.06 & 20.46 & 31.02 & light brown & $17-1046 \mathrm{TCX}$ \\
\hline 6 & iron sulphate & 39.11 & 2.01 & 20.66 & olive brown & $17-0636 \mathrm{TCX}$ \\
\hline
\end{tabular}

$\mathrm{L}^{*}-$ lightness

$\mathrm{a}^{*}-$ redness

$b^{*}-$ yellowness

Table 4.

Analysis of the colours obtained on Polish Lowland Sheep wool in dyeing process

\begin{tabular}{|c|c|c|c|c|c|c|}
\hline \multicolumn{7}{|c|}{ POLISH LOWLAND SHEEP } \\
\hline \multirow{2}{*}{ Sample No. } & \multirow{2}{*}{ MORDANT } & \multicolumn{3}{|c|}{$\begin{array}{c}\text { COLORIMETER } \\
\text { RESULTS }\end{array}$} & \multirow{2}{*}{ COLOUR } & \multirow{2}{*}{ PANTONE $^{\oplus \bullet}$} \\
\hline & & $L^{*}$ & $a^{*}$ & $b^{*}$ & & \\
\hline 0 & raw wool & 76.13 & 0.5 & 16.62 & golden cream & 13-0919 TCX \\
\hline 1 & no mordant & 51.72 & 19.38 & 46.94 & golden yellow & 15-0953 TCX \\
\hline 2 & alum & 55.31 & 15.34 & 50.14 & nugget gold & 16-0952 TCX \\
\hline 3 & sodium carbonate & 35.84 & 31.8 & 26.67 & rusty red & 16-1449 TCX \\
\hline 4 & citric acid & 68.71 & -1 & 57.86 & maize & 13-0746 TCX \\
\hline 5 & copper sulphate & 36.65 & 20.12 & 27.73 & light brown & $18-1160$ TCX \\
\hline 6 & iron sulphate & 40.17 & 5.14 & 27.73 & olive brown & $17-0840$ TCX \\
\hline
\end{tabular}

$\mathrm{L}^{*}-$ lightness

$a^{*}-$ redness

$\mathrm{b}^{\star}-$ yellowness

colour match without direct contact with one another.

Wool thickness and statistical quality parameters depending on the breed are presented in table 1 . The thinnest wool of the 3 selected varieties is Polish Merino. Żelaźnieńska wool has the purest and whitest colour. All samples of the washed wool were subjected to premordanting. Dissolved alum (alum - potassium aluminium sulphate $\mathrm{KAl}\left(\mathrm{SO}_{4}\right)_{2} \cdot 12 \mathrm{H}_{2} \mathrm{O}$ ) was added to the water, temperature $60^{\circ} \mathrm{C}$, and next the wool was added to this solution. The proportions were as follows: $8 \%$ alum - $100 \mathrm{~g}$ wool fibres. After the pre-mordanting process, it was the time for dyeing with Coreopsis flowers without additives and with the use of mordants: alum, soda, citric acid, copper sulphate and ferrous sulphate.

The result of colours obtained in Polish Merino, Żelazieńska and Polish Lowland Sheep wool in dyeing process can be found in tables $2-4$.

Ethical approval: The conducted research is not related to either human or animal use.

\section{RESULTS AND DISCUSSION}

The results of wool dyeing with $C$. tinctoria depending on the sheep breed and the used dyeing 
mordants are presented in tables 2-4.

Among the mentioned breeds of sheep, the brightest wool was obtained in Polish Merino and Żelaźnieńska. The measurement of colour with a colourimeter indicated that the most intense colour was obtained with use of sodium carbonate for the wool from Polish Merino breed - pure red, whereas Żelaźnieńska and Polish Lowland Sheep obtained brick-red colour.

The use of citric acid in the dyeing process of the Polish Merino and Żelaźnieńska wool gave the lemon yellowish colour, whereas the Polish Lowland Sheep wool - warm yellow. The results indicate that the basic colour of wool influences the intensity of colour after dyeing as well as the type of the used mordant, which determines the obtained colour. A whole range of very intense colours was obtained from very small flowers of $C$. tinctoria.

In conclusion, the mordant used for dyeing showed differences in colour and changes in the $\mathrm{L}^{*}$ brightness index similar to the results of study [1], although another plant was used for dyeing.

Conflict of interest: Authors declare no conflict of interest.

\section{REFERENCES}

1. Androsko R. Natural Dyes and dyeing. Dover 1971:83-84.

2. Dean J. Wild colour. New York 1999:86-87.

3. Schmidt-Przewoźna K. Barwienie metodami naturalnymi. Zawady 2009:18-23 [in Polish].

4. Schmidt-Przewoźna K, Skromak E. Thread of colourful yarn. Stalowa Wola 2013:1-49.

5. Bubanja N, Stešević D. Five new alien species in the flora of Montenegro: Coreopsis tinctoria Nutt., Ipomoea indica (Burm.) Merr., Lupinus regalis Bergmans, Physalis angulata L., and Solidago canadensis L. and new possible threats to the biodiversity. Zagreb Acta Botan Croatica 2017; 76:98-102. doi: http://dx.doi.org/ 10.1515/ botcro-2016-0048

6. Allan A. Perennial genera: Coreopsis. Greenhouse Grower 2000; 18(10):108.

7. Nagase A, Dunnett N. Establishment of an annual meadow on extensive green roofs in the UK.
Landsc Urban Plan 2013; 112:50-62. doi: http://

dx.doi.org/10.1016/j.landurbplan.2012.12.007

8. Abdureyim A, Abliz, M, Sultan M, Eshbakova A. Phenolic compounds from the flowers of Coreopsis tinctorial. Chem Nat Comp 2013; 48(6):10851086.

9. Tsai J, Chiu Ch, Chen Y, Lee M, Hao H, Hsieh M, et al. Hepatoprotective effect of Coreopsis tinctoria flowers against carbon tetrachloride- induced liver damage in mice. London BMC Complement Altern Med 2017:1-9. doi: http://dx.doi. org/10.1186/s12906-017-1604-8

10. Zhang Y, Shi S, Zhao M, Jiang Y, Tu P. A novel chalcone from Coreopsis tinctura Nutt. doi: http:// dx.doi.org/ 10.1016/j.bse.2006.05.005

11. Mota-Filipe, Bo Liu H, Cones P, Houghton P, Paulo A. Recovery of oral glucose tolerance by Wistar rats after treatment with Coreopsis tinctoria infusion. Phytother Res 2010; 24:699-705. doi: http://dx.doi.org/10.1002/ptr.2998

12. Lan S, Lin J, Zeng N. Evaluation of the antioxidant activity of Coreopsis tinctoria Nutt. and optimisation of isolation by response surface methodology. Acta Pharm Zagreb 2014; 64:369-378. doi: http://dx.doi.org/ 10.2478/acph-2014-0026

13. Zhang Y, Shi S, Zhao MX, Chai M. Coreosides A-D. C14-polyacetylene glycosides from the Coreopsis tinctoria Nutt. Biochem Syst Ecol 2006; 34:766-769.

14. Zhang Y, Shi S, Zhao M, Chai M, Coreosides $\mathrm{AD}$. C14-polyacetylene glycosides from the capitula of Coreopsis tinctoria and its anti-inflammatory activity against COX-2, Fitoterapia 2013; 87:93-97. doi: http://dx.doi.org/ 10.1016/j.fitote.2013.03.024

15. Li Y, Chen X, Xue J, Liu J, Chen X, Wulasihan M. Flavonoids from Coreopsis tinctoria adjust lipid metabolism in hyperlipidemia animals by downregulating adipose differentiation-related protein. Lipids Health Dis 2014, 13:193. doi: http:// dx.doi.org/ 10.1186/1476-511X-13-193

16. Dias T, Liu B, Jones P, Houghton PJ, Filipe H, Paulo A. Cytoprotective effect of Coreopsis tinctoria extracts and flavonoids on BHP and cytokineinduced cell injury in pancreatic MIN6 cells. J 
Ethnopharmacol 2012; 139:485-492. doi: http:// dx.doi.org/ 10.1016/j.jep.2011.11.038

17. Kicińska-Jakubowska A, Morales Villavicencio A, Zimniewska M, Przybylska P, Kwiatkowska E. Evaluation of wool quality parameters of Polish sheep breeds. Proceedings of the 4th International Conference on Natural Fibers (ICNF): Smart
Sustainable Solutions. 2019 Porto, Portugal. 376377.

18. Shahparvai MR, Safapour S, Gharanjig K. Study on color characteristics of wool dyed with crude and extracted Prangos ferulacea natural dye. The 6th International Color \& Coating Congress, Institute for Color Science and Technology, 10-12 November 2015 Tehran, Iran. 